\title{
The Indian Origin of Romani people as a Founding Myth in Eastern European Museums
}

Douglas Neander Sambati ${ }^{1}$

\section{Introduction}

This article analyses three museums - the Muzeum Romské Kultury (MRK) in Brno/Czech Republic, the Muzej Romské Kulture (MRKu) in Belgrade/Serbia, and the Roma Ethnographic Museum (REM) in Tárnow/Poland - and part of its exhibitions which can be considered as elements of the Romani Nationalism. The main objective is to demonstrate how these museum institutions support a broad narrative about a common Indian origin of Gypsy/Romani populations.

It will be discussed below how the aforementioned museums - by means of their exhibitions, websites, events or any other kind of official production - support sets of representations which allow a formation of an umbrella rhetoric about the group known, taken and self-ascribed as Gypsies and/or Roma. This discourse, then, is able to shelter all different groups within this population in a holistic manner, based on a narrative formed by essentializations, exoticizations and generalizations. Therefore, the argument will be developed from now onwards by establishing a dialogue of elements which essentialize - in the sense that they imply natural and intrinsic characteristics - some aspects of Roma history and

\footnotetext{
${ }^{1}$ Grupo de Pesquisa Estudos Interdisciplinares de Patrimônio Cultural da UNIVILLE. dnsambati@gmail.com
} 
culture. In plain words, it is possible to find within these museums some specific deliberation which sustains none (or little) doubt that some characteristics are part of a claimed Romani way of life. The exoticizations support a narrative in which cultural practices belong "only" to Gypsies/Roma, emphasizing the group as different and sealed. As a result, such 'natural/organic' and 'exclusive' customs must be common to the big group - otherwise there is not a creation of an encircling Roma Nation -, and, therefore, to reinforce the umbrella Romani rhetoric, all these characteristics must be organized in a generalizing way. In summarizing, the political and ideological standing point of the museum, although blurred by the supposedly scientific and objective museal institution, elaborates discourses which naturalize some customs, elaborate upon cultural patterns restrictive to Gypsies/Roma and generalize all those characteristics, in order to shelter as many people as possible. The utmost layer of such practices lay in a founding myth $^{2}$ of their Indian Origins.

This article is divided in three parts, plus the Introduction and the Final considerations. The first part briefly presents the concept of Romani Nationalism elaborated during the development of my Ph.D. thesis entitled "Historical Sociology of the Romani Nationalism: Foundations, Development, and Challenges". The second part, The Indian origins and the broad rhetoric about the Gypsy/Romani Culture, conceptualizes the Indian origins as a founding myth and discusses how it might be observed in these museums. The last part is called Contradictions on the management of memory and discusses the role of museums as places to representations of memory but which, similarly, are locals where the represented memory is legitimized and, often, (continuously) reshaped.

\footnotetext{
${ }^{2}$ Founding myth (or in the original mito fundador) is a concept coined by Brazilian philosopher Marilena Chauí.
} 
This paper understands throughout that museums have a role in the process in which the concept of Roma is generalized in an attempt to rewrite and relabel $^{3}$ Gypsy memory as a Roma history; and relies on the theories of museology and sociomuseology, and the theory of representations - both practices of representations and representations of practices.

\section{Brief characterization of the Romani Nationalism}

The present article sees that the work, the behaviour and the mind-set of Romani and Romani-Friendly organizations - these museums are included in these categories - can be considered a nationalist movement. Mostly because it was (still is) a set of practices and discourses developed by an intellectual elite and activists, which aims for the general recognition of their (claimed) group as a Nation. However, the characteristic of not aiming for a State makes it a unique type of nationalist movement. Romani Nationalism, therefore, does not fit within the classic or any previous nationalist theories ${ }^{4}$, but follows its own path, adapting key concepts. As a concept, nation refers to as a group with a

\footnotetext{
${ }^{3}$ In Portuguese, the verb requalificar ( $r e+$ qualificar. The prefix ' $r e^{\prime}$ brings the idea that something is being made again, meanwhile the verb 'qualificar' might be translated as 'to qualify', 'to describe' or 'to designate') is used when discussing about the rethinking and the rewriting on historiographic knowledge aiming to develop a different status to a given subject. In studies about Cultural Heritage such concept is borrowed from the architecture with current meanings related with changes in an area and/or property, giving a different status to the place, without erasing the previous diverse uses of the site. In plain words, while the idea of renovation brings some aesthetical understandings upon the space, requalificar corresponds to the political, social and economic interests related to the whole process (Bezerra \& Chaves, 2014). This research understands that the better word to characterize the work on the Romani culture, history, identity and so forth would be requalificar, and the closest translation to English of this concept would be the word relabel.

${ }^{4}$ To an in-depth study of the classic theoreticians on nationalism read Ernet Gellner, Miroslav Hroch, Anthony Smith and Otto Bauer.
} 
nuclear, basic and broad shared culture, with a communal historical past expressed in a remote origin, though not necessarily attached to a specific clearly defined land in current times. The aspiration and attempt is not the creation of a State, mostly because States had never been kind or helpful to Gypsy/Romani populations. Nevertheless, there are attempts of self-determination which would be enforced through a state-like organization in an international level (even though it is not clear which one). The ideal of who are the Roma is malleable and uncertain, rhetorically associated with cultural practices but pragmatically more closely connected with social-economic issues. In plain words, the fight against Antigypsyism is sometimes structured as a nationalist movement, in order to humanize the subjects known, called or self-ascribed as Gypsies. Gypsies were relegated in non-Gypsy/non-Romani social levels to a people without culture and, therefore, their behaviour would be explained by their biological condition. Nations, on the other hand, are formed by ties based on cultural characteristics. Therefore, to rhetorically transform Gypsies into a Roma Nation might have been seen as a way to fight for a better life for the Gypsy/Romani population. In a brief way, it is a nationalist movement, but a very specific one. The discussion about this nationalist rhetoric will below be discussed on one of its faces which is the Indian origins rhetoric bringing a common past to all Gypsy/Romani populations.

The Indian origins and the broad rhetoric about the Gypsy/Romani Culture

The Indian origins constitute one of the key elements in the elaboration of the narrative of the Romani Nationalism. This interpretation highlighting historical common roots is shared by numerous authors, as Hancock (2001, p.VIII) claims: 
"[...] the Indian roots are both demonstrable and undeniable, there is reason to believe that our Romani language, and a good part of our core culture, only crystallised once the migration westwards had reached Anatolia, which it seems to have done in less than fifty years after leaving India".

Other scientific works also bring up this view about the origins, stating few doubts on the topic, in an objective and assertive choice of words. For example McGarry (2008, p.453) says "On arriving from India, Roma dispersed across Europe and their heterogeneity and diversity have prompted some to describe this community as an 'archipelago'". Liegeois and Gheorghe (1995, p.7) affirm:

The first Roma/Gypsy groups reached Europe from the East in the fourteenth and fifteenth centuries. At this time, they still remembered their homeland, as testified by numerous documents dated between 1422 1590, a period during which their Indian roots were gradually obscured by legends of Egyptian origins.

The attempt to bring Gypsy/Roma populations and India closer goes beyond the academic research and discourses. Marushiakova \& Popov (2004) bring the information that during the 1990s, when the direction of the IRU was not so rigorous regarding the concept of a nation without a state, there were discussions about the fight for the recognizing of the Roma as a people of Indian origins. This discussion went further and it was even considered the chances to issue Indian passports to Roma people (Marushiakova \& Popov, 2004).

Such narratives support the assumption that all the Roma have the same origin and, therefore, are part of a same group nowadays. Therefore, the Indian Origin works as a founding myth of 
the Romani people. The founding myth (Chauí, 2000) is a whole set of representations situated out of History. It is temporalized at a remote past, in a moment that cannot be precisely defined - and works very well in filling any kind of gap precisely because of that characteristic. The founding myth attempts to be immutable and eternal, live at the present and justify several actions on current everyday life. The idea of a fixed origin in India as a founding myth simplifies the discussion of several complex questions, such as: 1 . is it possible to picture the existence of an Indian nation based on ethnic principles more than a thousand years ago? 2 . What were the social and cultural characteristics of the people who supposedly left those lands? 3. What happened with these populations throughout the time it took them and their descendants to enter Europe? 4. Are all Gypsies/Roma today direct descendants of those who migrated? The most important thing in the founding myth is establishing an origin that must be strong enough to fill some questions and malleable enough to adapt to different contexts and situations. The founding myth concept is also beneficial in understanding how the Indian origins are used to legitimize, justify and illustrate the Romani culture, believes and behaviour. The museums herein discussed, whether subtly or otherwise, help to reinforce the mythological origin in the East.

The Muzeum Romské Kultury's ${ }^{5}$ website tells a part of its story. The MRK was founded in 1991 after the initiative of Roma intellectuals and it is, since 2005, funded by the Culture Ministry of the Czech Republic. However, the first ideal about the construction of a memorial that would organize Romani history and memories has its roots in the 1960s, the process being interrupted by the Soviet occupation in 1968 (Schuster, 2015). The museum building is located in an area of the city of Brno which is known for its historical and current concentration of people identified as Gypsies.

\footnotetext{
${ }^{5}$ Gypsy Culture Museum. Author's free translation.
} 
As stated during visits to the museum and via interview with Mr. Michal Schuster, the exhibition of MRK has been prepared so that a visitor who has no knowledge about Romani history can understand it. Thus, the exhibition is divided into six rooms; however this article will focus on the first one which presents, among other information, a narrative about the Indian origins of the Gypsy/Romani people. Such connections are affirmed with the use of Indian motifs in the room and displays stressing the similarities between Indian and Gypsy/Romani dress codes. Moreover, a video presenting Gypsies/Roma groups in the Middle-East - a mid-way between India and Europe -, a multimedia installation showing the similarity between the Romani language and Hindi and also the Romani national flag side by side with the Indian flag. Finally, at the point of transition to the second room, there is a map showing the claimed path of the Roma people, since their departure from where today is India up to the arrival and spread across Europe.

The concordance with this theory is also seen in some texts presented on the website of the museum. For instance:

The permanent exhibition called "The Story of the Roma" will introduce you to the history of the Roma people. It will guide you from the times of their ancestors in the ancient India through the arrival of the Roma in Europe in the $11^{\text {th }}$ century over to the events of the Second World War and present days (Muzeum Romské Kultury, 2016).

Here, it is possible to see how the History of the Roma people has, in the discourse of the MRK, a clear beginning: the lands of current India. This aggregator discourse as a historical umbrella encompassing the whole Gypsy/Romani population is also found in other museums, such as in the Muzej Romské Kulture ${ }^{6}$.

\footnotetext{
${ }^{6}$ Roma Culture Museum. Author's free translation.
} 
In the first half of 2000 the Roma Community Centar 8. april was created in Belgrade, an NGO which has as its main target researching about "Gypsy/Romani culture". Through this work, the NGO aims to improve the knowledge about the Roma within the general population and the Gypsy/Roma people themselves. In 2009, the organization, with the help of the Belgrade City Hall, was able to open the MRKu (Muzej Romské Kulture, 2016).

From the website of the museum it was not possible to gather much information, mostly because it is written in Serbian ${ }^{7}$. There is, however, a subtitled video available on YouTube, consisting of four parts, with images, recordings and interviews during the renovation of the museum's building, the opening party and other moments. The statement made by Rajko Đurić, a former president of the International Romani Union, is particularly relevant because he stresses the belief about the origins of the Roma people: "As for the name Roma, namely Rom in singular and Roma in plural - already that phoneme indicates clearly that we are talking here of Indian origins, [...]" (Acković, 2010).

In Poland a similar approach of Indian origins can be seen. The REM is a subdivision of the Muzeum Okreggowe w Tarnowie $^{8}$, which deals with ethnography and has a permanent exhibition on Gypsies/Roma opened during the $4^{\text {th }}$ International Romani Union Congress, held in in Warsaw, in the year of 1990 (Marushiakova \& Popov, 2016). The history of the museum itself goes back to the year 1927. In 1949, the museum was nationalized and adopted the

\footnotetext{
7 There were attempts to contact via email but no answer has been received. During two days, in September $20^{\text {th }}$ and $21^{\text {st }}, 2016$, I visited Belgrade to, among other tasks, visit the MRKu. Unfortunately, hours before the visit, the researcher on Roma people Andrej Kubiček, warned me that after some attempts to contact the museum staff he received the information that the institution was closed, with the whole collection covered in dust and a shameful way - their words

${ }^{8}$ Regional Museum of Tárnow. Author's free translation.
} 
The Indian Origin of Romani people as a Founding Myth Douglas Sambati

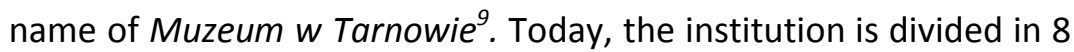
venues, including the Ethnographic Museum (Muzeum Okręgowe w Tarnowie, n.d.).

At the museum located in Tárnow, there are two main elements claiming the Indian origins. First, in the passage from the first to the second room, a map is displayed showing the way travelled by the Gypsies/Roma from where is currently India to Europe, with arrows showing their spread throughout Europe (similar with the map found in the MRK). Later, at the last room there is this display:

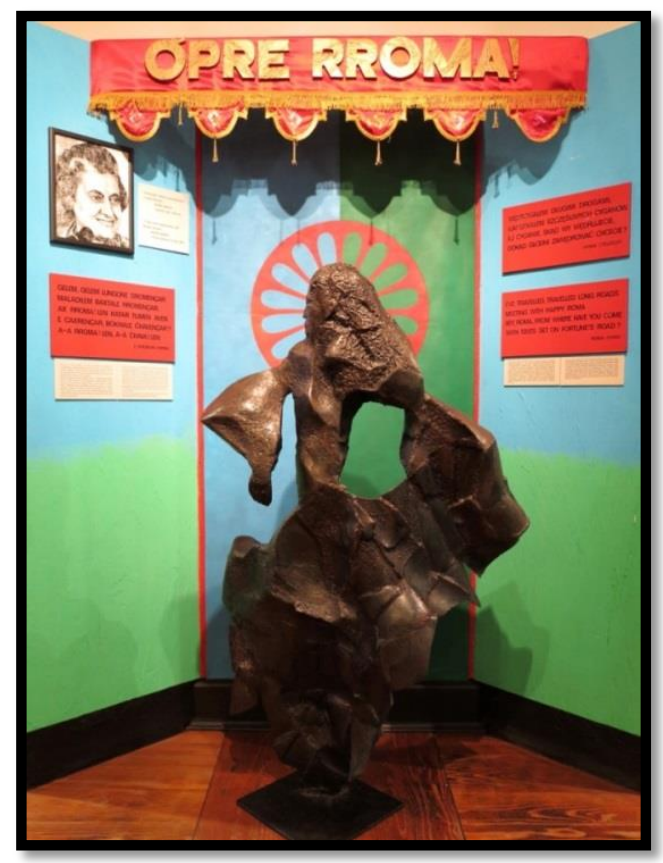

Image 1 - Exhibition at the Ethnographic Museum in Tárnow (Miura, 2016)

\footnotetext{
${ }^{9}$ Museum of Tárnow. Author's free translation.
} 
In image 1 it is possible to be seen the picture of the former prime minister of India, Indira Gandhi. Indira ruled India from 1966 until 1977 and, after losing one election, returned to power in 1980, where she remained up to her murder in October $31^{\text {st }}, 1984$ ('Indira Gandhi: prime minister of India', 2017). The picture of a prominent Indian politician side by side with the Romani flag suggests the relations between the Roma Nation and the Indian subcontinent.

However, different scholarly works express a certain degree of reluctance concerning this certainty upon the Indian Origins. Will Guy (2001) recalls that the most important bond that could tie the current Gypsy/Romani population of Europe - and of the whole world - with an ancient Indian population is the language. However, he stresses that the Romani language today is spoken by less than half of the Gypsies/Roma in Europe and, even among them, there are between 50 or 100 different dialects, many times intelligible only in very basic senses connected with everyday life.

Ládanyi and Szelényi (2006, p.125) say:

Roma political activists promote the term Roma in order to create a positive identity and to mobilize various groups, many of which, at least according to Judith Okely, do not share a common ancestry. The term Roma comes from the Romany language, which is related to Sanskrit - the only hard evidence of the Indian origins of the Gypsies. In Romany language, Rom or Roma means husband, or the generic term for man. The roots of this term in Sanskrit are quite different however. In Sanskrit, dombe or doma refers to a low caste musician. Nevertheless, Roma activists wanted to manufacture a positive alternative to gadjo. Thus, if you are not gadjo, ethnic, or other, you must be a man or a Roma.

For these scholars, the attempt to create a link between the current Gypsies/Roma and ancient India is either a forced 
interpretation of some signs or irrelevant from the point of view of the broad Gypsy/Romani population. Stewart (1999) provides similar insights. Reflecting on his research with Gypsies, he observes that they are aware of the intellectual elite's attempt to frame a common origin for all the Gypsies. Nevertheless, this average population is little or not at all interested in this relabelling: "[...] they know that their ancestors are said to come from India but display no interest in this fact" (Stewart, 1999, p.92) ${ }^{10}$.

Thus, the Indian origin as a founding myth brings the claimed Romani culture to levels of representations and legitimacy closer to the western patterns, i.e., the generally accepted idea of being (potentially) a nation as long as common roots (which provides common cultural practices) can be traced and celebrated. In turn, Roma scholars and intellectuals who support the idea of a Roma Nation operate with the mythological Indian origin as a tool in the fight for a better social, economic and political placement of the Gypsy/Romani population.

\section{Contradictions on the management of memory}

Beyond their exhibitions and statements, the very existence of museums works as a referential point, as a space which changes the status of the memory highlighted. Chagas (2010) discusses the fight for the right to memory ${ }^{11}$ which took place around the world after the end of the Second World War. Into his view, this fight for

\footnotetext{
${ }^{10}$ It is not the intention of this work to gloss over the historical context which might have forced the whole population of Gypsies/Roma to stop using the Romani language, to deny or pay little attention to the claimed Indian origins. As previously attested, there are evidences of both an Indian origin and even of a shared language. However, this work focuses in analyzing how such facts are politically shaped and instrumentalized.

${ }^{11}$ In the original: Direito à memória. Author's free translation.
} 
the right to memory, materialized in a desire to museums ${ }^{12}$, resulted into an exponential growth of the number of institutions of this kind in the $20^{\text {th }}$ century. According to Chagas, Primo, Storino, \& Assunção (2018) with the museums transformations during the $20^{\text {th }}$ century local museums connected with communities and minorities around, mostly in Portugal and Latin America but everywhere, became places to resist:

Many museums were born as an answer to the needs of specific social groups in protecting and disseminating memories, heritage, and cultural expressions; but they also grew out of the shrewd understanding that it is possible to use museums without any shame - just as museums have been always used by the dominant social groups -, in favour of certain projects, of very specific struggles ${ }^{13}$ (Chagas, Primo, Storino, \& Assunção, 2018, p.98).

In different words, during the $20^{\text {th }}$ and the 21th centuries, several groups started a struggle for legitimisation of their culture and costumes in the eyes of "the other". In this way the museum can be seen as

[...] new war machines stored in favour of social 'empowerment' of those who have been historically subordinated and expropriated from the right to construct and narrate their own Histories, their memories, their cultural heritage and their museums ${ }^{14}$ (Chagas, 2010, s.p.).

\footnotetext{
12 In the original: Vontade de museu. Author's free translation.

${ }^{13}$ In the original: "Muitos desses museus nasceram como resposta às necessidades de grupos sociais específicos proteger e divulgar memórias, patrimónios e expressões culturais; mas nasceram também da compreensão sagaz de que é possível utilizar os museus, sem nenhum pudor, à semelhança do que sempre foi feito pelos grupos sociais dominadores, a favor de determinados projetos, de lutas bem específicas". Author's free translation.

14 In the original: [...] novas máquinas de guerra colocadas a favor do "empoderamento" social daqueles que historicamente foram subalternizados e
} 
The battle of such war machines is fought in the fields of representations. Museum exhibitions can thus be seen as a set of representations of practices organized to bring up something that is far away or no longer exists (Chartier, 1990). In this case, what is far away is a space on the past where the contemporary Roma elite claim a common origin to all the Gypsy/Romani populations. This immaterial and rhetorical space, however, is built through elements which - in the understanding of the elaborators of the exhibition might brand their position in the world, and objects that represent values which would mark or indicate their existence as a community (Chartier, 1990).

Joel Candau (2011, p.23) calls this process and this narrative metamemory:

[...] It is, on the one hand, the representations that each individual makes upon her/his own memory, the knowledge that she/he has related to it and, on the other hand, what she/he says about her/his memory, the dimensions which "are connected to the individual's affiliations with her/his past" and, likewise, $[\ldots]$, the explicit construction of the identity. Metamemory is therefore a claimed memory ${ }^{15}$.

Although Candau referred in this quotation to personal experiences, it seems that this approach can be used for a better understanding concerning processes of construction of group identities of nationalist kind. The memories which the group and/or an individual invoke are self-representations considered to be

expropriados do direito de construir e narrar suas próprias histórias, suas memórias, seus patrimônios e seus museus". Author's free translation.

${ }^{15}$ In the original: "[...] que é, por um lado, a representação que cada indivíduo faz de sua própria memória, o conhecimento que tem dela e, de outro, o que diz dela, dimensões que remetem ao 'modo de afiliação de um indivíduo a seu passado' e igualmente, [...], a construção explícita da identidade. A metamemória é, portanto, uma memória reivindicada, ostensiva". Author's free translation. 
eloquent for the individual or collective identity and selected to indicate their particularities while engaging in the relationship with other groups. This is the process that occurs in mounting a museum exhibition: one organizes the History that is believed to be the most accurate - or convenient - version to be shown to the public. However, Candau (2011) draws attention to the fact that these representations are not, in any way, unanimously acknowledged as such within a group. For this author, the individuals of a community hardly share the same ideas upon the "perfect" representations about themselves and the same understandings on the symbolism of the material elements that could depict their identity. What is designated as metamemory would be in fact a holistic rhetoric, i.e., significant symbolic elements which the group shares with less individual resistance. Moreover, the process is a power game in which these representations are formulated through a social construction of identities - not always in a peaceful way.

Candau's thought finds parallel in Chartier's historical analysis of representations:

The representations of the social world built in this way, although aspiring to a universality of diagnosis based on reason, are always determined by the interests of the group in which were forged. So, in all cases, it is necessary to refer and place discourses with the position of those who used the rhetoric ${ }^{16}$ (Chartier, 1990, p.17).

But Chartier goes further. He stresses how important it is to keep in mind that representations are constructed by one group and aimed to be understood by another. In this sense, the message

\footnotetext{
${ }^{16}$ In the original: "As representações do mundo social assim construídas, embora aspirem à universalidade de um diagnóstico fundado na razão, são sempre determinadas pelos interesses de grupo que as forjam. Daí, para cada caso, o necessário relacionamento dos discursos proferidos com a posição de quem os utiliza". Author's free translation.
} 
represented will not always find among those who will receive the information the same symbolic value that it was intended to communicate, back in the emission. Thus, the representations of practices and values are issued by the emissaries, based on their cohabitation and exchange of symbolic values, meanwhile the receptor group is supposed to decode the message based on their context and understanding about the symbols used in communication. It is never a predictable communication.

In this way, is important for emissaries to use symbols which are more likely to find an anchorage among the receptors. That is why, in the case which is being studied here, it might be advisable to the emissaries of the Roma Nation message to adorn the elaboration of the Roma/Gypsy nationality with concepts and ideals that are already used to symbolize a nation. In this sense, stressing a founding myth which in the case of the Roma nationalist movements can be encountered in the Indian origins.

Certain oversights and generalizations seem to characterise the representations concerning the Gypsy/Romani historiography in the museums. As it is important to highlight, this article does not entail that there is any intentional attempt of falsehood being told by the museums. Therefore, no statements here should be understood as implying that these institutions are working in conspiracy to create from out of nowhere a brand new - or fake historiographic narrative encompassing all these groups scattered around the world. Nevertheless, said rhetoric and exhibitions are the result of a process of social, cultural and economic replacement of the populations which historically have been labelled under the nomenclature of Gypsy/Romani populations in relation with nonGypsies/Romani. This operation is led by an intellectualized Romani group, who supports and reinforces the aforesaid reframing and relabelling of the Gypsy/Romani status. Yet, any organization or institution related with the Roma people is touched by this 
mechanism of reclassification and, in that way, they are - in several different levels - its reflection. In short: all the proceedings around the Roma topic are both the result and creation of the attempt to change the Gypsy/Roma status - whether economic, social, political, cultural and so on. But, as Candau stresses, oblivion is not necessarily a mistake or a failure, but sometimes it is a manner to construct representations about the past in ways that make sense for the current needs of one group in a continuous identification interplay game. And, this kind of construction and reconstruction, these lacks, absences or rearrangements of memories of the past, have the aptitude to say much about one given society and their values and their plans for the future (Maslowski, 2014).

Almost all, if not all, scholars who study Gypsies/Romani issues agree that this group is, actually, a very heterogeneous group, consisting of different populations characterised by distinct languages/dialects, customs and cultures, always in mutation given the contact with other groups socially seen as Gypsies/Roma or non-Roma. Fraser (1996), for instance, attests the multiplicity of dialects which the Romanes language is composed of and Guy (2001) calls attention to the fact that not all Gypsy/Roma groups speak this language. To exemplify such diversity, it is possible to use Kjučukov (2013). In his work, this scholar discusses two Roma groups settled close to each other in the city of Çatalca/Turkey. On the one hand, the people who call themselves Kibar Çingene (a Turkish version to the English word Gypsy) do not know how to speak the Romani language and identify themselves with the Turkish nationality. On the other hand, the other group speaks the Romani language and they identify themselves as Roma. The ethnic borders and patters are thus very fluid.

These examples emphasize how museums usually, including the museums studied in this article, have a policy of generalization of the identity of the people known as Gypsies, mainly under the 
label of Roma. Despite all the hardly contestable plurality of faiths, languages and cultures, all the museums present themselves as museums of 'the' Roma or Gypsy people. Through their names, there is a semi-mute claim that they represent all the Roma people, as if they were all the same.

The REM presents an exhibition named Roma - History and Culture. Although in their displays and texts might make reference to plurality - for instance, there are three versions of the Our Father: in two Polish dialects of the Romani language and in the "standardized" Romani language -, in its name and headlines what prevails is the holistic concept of Roma or Gypsy. The MRK, for instance, claims the following on its website: "We are paving the way to a new understanding of the roots of Romani identity". This sentence does not clarify which one, from all the different Gypsy/Roma populations, is going to be displayed in the museum. Also, inside the exhibition, the only clear differentiation between Gypsies/Romani populations from the lands of the current Czech Republic and Slovakia: i.e., the difference between Roma people comes from elements detached from them. In other words, the differences are based on the land and countries where they live (or used to live) and not within their culture and history. In a very similar way, in its explanation about the programs for schools, the museum affirms that it brings the visitors closer to the Romani culture. An analogous situation can be seen in the video about the MRKu, in Belgrade. Right at the beginning of the recording, Dragolijub Acković states that anyone who visits the museum will have contact with the true Roma culture (Acković, 2010, my italics), again with no highlight on the plurality characterizing Gypsy/Romani populations $^{17}$.

\footnotetext{
17 Not to mention the message that something like "true Roma culture" exists (implicitly suggesting that there might be "false" Romani cultures around the world).
} 


\section{Final considerations}

As pointed earlier these populations are plural. Usually, when the processes of essentialization, exoticization and generalization takes place, it goes hand in hand with the process of relabelling Gypsy memories as a single Roma historiography. After all, in the discussions found in almost these museums the Gypsies are nominated as 'Roma' in a generalized way ${ }^{18}$ and connecting these populations with little reflection to a distant past in a distant land. This shows, perhaps, an early plan for the future, an attempt to organize a new discourse to teach the new generations a new history about these people. What is more, this new History would place a new status in its relation with other national narratives, now deemed on an equal basis.

The MRK affirms that it seeks to educate new generations through their educational programs and workshops. The MRKu follows in a very similar way, asserting its will "to inform and educate the young Roma" (Acković, 2010), and the will, confirmed by Rajko Đurić's speech, to save for posterity the - singular - Roma culture. It is possible to see a relabelling of a history full of persecutions and cheerless moments as a new one, related with culture and positive aspects. Hence, considering the plurality that characterise the Gypsy/Romani people, it was necessary to articulate common aspects - whether truthful or not, is not the target of this work to discuss - which would legitimise this new identity, a Roma identity. In this process, museums are playing an important role, with their aura of truth meant to enforce and legitimize the narratives which constitute the core of this discussion.

\footnotetext{
${ }^{18}$ It is important to highlight here that there were groups considered as Gypsies that always named themselves Roma or similar, but what the museum rhetoric does is different.
} 


\section{Bibliography}

Acković, M. (2010). Muzej Romské Kulture deo 1/4 [Online] (Vol. 1). Belgrade. Retrieved from https://www.youtube.com/watch?v=Ge05K4uubzc Bezerra, A. M. M., \& Chaves, C. R. C. (2014). Revitalização Urbana: Entendendo o processo de requalificação da paisagem. Revista Do CEDS, 1, 1-16.

Candau, J. (2011). Memória e identidade. São Paulo: Contexto.

Chagas, M. de S., Primo, J., Storino, C., \& Assunção, P. (2018). A museologia e a construção de sua dimensão social: olhares e caminhos. Cadernos de Sociomuseologia, 55(11), 73-102.

Chartier, R. (1990). A história cultural: entre práticas $e$ representações. Rio de Janeiro: Bertrand.

Chagas, M. (2010, September 14). + Direito à Memória. Retrieved 7 March 2017, from

http://redemuseusmemoriaemovimentossociais.blogspot.com/201 0/09/direito-memoria-mario-chagas.html

Chauí, M. de S. (2000). Brasil: Mito fundador e sociedade autoritária. São Paulo: Fundação Perseu Abramo. Retrieved from http://www.usp.br/cje/anexos/pierre/brasil_mitofundador_e_socie dade_autoritaria_marilena_chaui.pdf Fraser, A. M. (1996). The Gypsies (2nd ed). Oxford: Blackwell. Guy, W. (2001). Romani Identity and post-Communist policy. In W. Guy (Ed.), Between past and future: the Roma of Central and Eastern Europe (pp. 3 - 32). Hertfordshire: University of Hertfordshire Press. 
Hancock, I. (2001). Foreword. In Between past and future: the Roma of Central and Eastern Europe (pp. VII-IX). Hertfordshire: University of Hertfordshire Press.

Indira Gandhi: prime minister of India. (2017, September 28).

Retrieved 27 October 2016, from

https://www.britannica.com/biography/Indira-Gandhi

Kjučukov, C. S. (2013). Projection hypotheses in language and identity among Muslim Roma. In Roma Identity and Antigypsyism in Europe. Munich: LINCOM Europa.

Ladányi, J., \& Szelényi, I. (2006). Patterns of exclusion: constructing Gypsy ethnicity and the making of an underclass in transitional societies of Europe. Boulder: East European Monographs.

Liegeois, J.-P., \& Gheorghe, N. (1995). Roma/Gypsies: A European Minority. London: Minority Rights Group International. Retrieved from http://www.synigoros.gr/resources/roma/sxetika-genikaeggrafa/romareport.pdf

Marushiakova, E., \& Popov, V. (2004). The Roma - a Nation without a State? Historical Background and Contemporary Tendencies.

Retrieved 10 August 2016, from http://www.nomadsed.de/fileadmin/user_upload/redakteure/Datei en_Publikationen/Mitteilungen_des_SFB/owh6marushiakova.pdf Marushiakova, E., \& Popov, V. (2016). Roma museums. In Roma Culture: Myths and Realities. Munich: Lincom Academic Publisher. Retrieved from https://www.academia.edu/27156243/Roma_Museums Maslowski, N. (2014). Politika paměti jako nástroj manipulace a morálky. In N. Maslowski \& J. Šubrt (Eds.), Kolektivní pamět': $k$ teoretickým otázkám (Vol. 1, pp. 69-81). Prague: Karolinum.

McGarry, A. (2008). Ethnic Group Identity and the Roma Social Movement: Transnational Organizing Structures of Representation. Nationalities Papers, 36(3), $449-470$. 
Douglas Sambati

Miura, K. (2016). Exhibition at the Ethnographic Museum in Tárnow [Photography]. Retrieved from http://kodography.com/

Muzej Romské Kulture. (n.d.). O osnivaču Muzeja. Retrieved 10 August 2016, from http://romamuseum.rs/onama.html Muzeum Okręgowe w Tarnowie. (n.d.). Historia muzeum. Retrieved 12 July 2016, from

http://www.muzeum.tarnow.pl/historia_muzeum.php

Muzeum romské kultury. (n.d.). Permanent exhibition - The Story of the Roma. Retrieved 10 August 2016, from http://www.rommuz.cz/en/exhibitions-andprogramme/permanent-exhibition-the-story-of-the-roma/ Schuster, M. (2015, December 10). Meeting - 09.10.2015.

Stewart, M. (1999). The puzzle of Roma persistence: group identity without a nation. In Romani culture and Gypsy identity (pp. 84-98). Hatfield: University of Hertfordshire Press. 